\title{
Biological aspects of crosses between Triatoma maculata (Erichson, 1848) and Triatoma pseudomaculata Corrêa \& Espínola, 1964 (Hemiptera: Reduviidae)
}

\author{
Carlota Josefovicz Belisário, Grasielle Caldas D'Ávila Pessoa, Liléia Diotaiuti+
}

Laboratório de Triatomíneos e Epidemiologia da Doença de Chagas, Centro de Pesquisa René Rachou-Fiocruz Av. Augusto de Lima 1715, 30190-002 Belo Horizonte, MG, Brasil

Due to morphological similarities between Triatoma maculata and T. pseudomaculata, which comprise the "maculate complex", both had been regarded as the same species until 1964. Considering that the studies on triatomine hybridization permit hypotheses formulation concerning origin and divergence of species, enabling a quantitative analysis of taxonomic relationships between species, the present investigation was aimed at broadening further understanding related to the capacity of hybrid production by determining the degree of reproductive isolation between $\mathrm{T}$. maculata and $\mathrm{T}$. pseudomaculata. Our results have demonstrated that $\mathrm{T}$. maculata and $\mathrm{T}$. pseudomaculata showed no differences regarding reproduction patterns and they are able to cross, generating infertile hybrids.

Key words: Triatoma maculata - Triatoma pseudomaculata - hybrids - Triatominae

Triatomines are hematophagous insects belonging to the order Hemiptera, family Reduviidae, and subfamily Triatominae, comprising a group of 138 species (Galvão et al. 2003, Forero et al. 2004, Costa et al. 2006, Costa $\&$ Felix 2007). The epidemiological importance of such group lies in their potential capacity of transmitting the etiological agent of Chagas disease, the flagellate protozoan Trypanosoma cruzi (Chagas 1909).

In epidemiological terms, T. maculata is considered a species of secondary importance (Lent \& Wygodzinsky 1979). It can occur in domestic, peridomestic, and silvatic habitats, frequently found in hen houses, corrals, nests of birds (Lent \& Wygodzinsky 1979, Torrealba et al. 1985, Carcavallo et al. 1997), nests of small mammals (Torrealba et al. 1985), pig pens (Lent \& Wygodzinsky 1979), and pigeon coops, although its natural ecotope seems to be palm tree crowns and dry trees (Carcavallo et al. 1997). T. pseudomaculata is also found in hollows and under the bark of dry trees (Noireau et al. 2005). It is also a species of secondary epidemiological importance, often found in peridomestic habitats associated with domestic fowl (Silveira \& Rezende 1994, Borges et al. 1999, Sarquis et al. 2006).

Due to morphological similarities, most triatomine species can be grouped into specific complexes (Carcavallo et al. 2000), which have been much discussed in order to reassess species distinction and establish precise terms for their identification. The Lent and Wygodzinsky (1979) revision included T. maculata and T. pseudomaculata in the 'infestans complex' together

+Corresponding author: diotaiuti@cpqrr.fiocruz.br Received 13 December 2006

Accepted 7 March 2007 with 19 other species, although Carcavallo et al. (2000) grouped the two together as the 'maculata complex'.

T. maculata and T. pseudomaculata are allopatric species (Figure). According to Schofield (1988), T. maculata could be a derivative of $T$. pseudomaculata, geographically separated by association with migratory birds, although Santos (2003) and Hypša et al. (2002) rejected the hypothesis that $T$. maculata and $T$. pseudomaculata had the same origin.

In their original description of T. pseudomaculata, Corrêa and Espínola (1964) noted that hybrids could be obtained from crosses between $T$. maculata from Roraima, Brazil, and T. pseudomaculata from Paraíba, Brazil, but with a high number of non-viable eggs - particularly when $T$. pseudomaculata males were crossed with T. maculata females. Later, exploring further crosses, including T. pseudomaculata from Paraíba and Minas Gerais, Brazil, Espínola (1974) reasserted the validity of $T$. pseudomaculata as a separate species and, by observing differences between specimens from the two localities, suggested recognition of $T$. pseudomaculata pseudomaculata from Northeast Brasil, and T. pseudomaculata minasensis from Minas Gerais, as distinct subspecific entities. Perlowagora-Szumlewicz and Correia (1972), Perlowagora-Szumlewicz et al. (1974), Perlowagora-Szumlewicz (1976), in a series of studies of hybridization of Triatominae, concluded that viable reciprocal crosses (male of one species with female of another, and vice versa) between T. pseudomaculata and T. sordida demonstrated genetic proximity between these two species, whereas unilateral crosses (successful in only one direction, male of one species and female of the other, or vice versa) demonstrated more distant relationships, as between T. pseudomaculata and T. infestans.

Considering that triatomine hybridization (a) allows formulation of hypotheses concerning origin and divergence of species, (b) may help understand the systemat- 


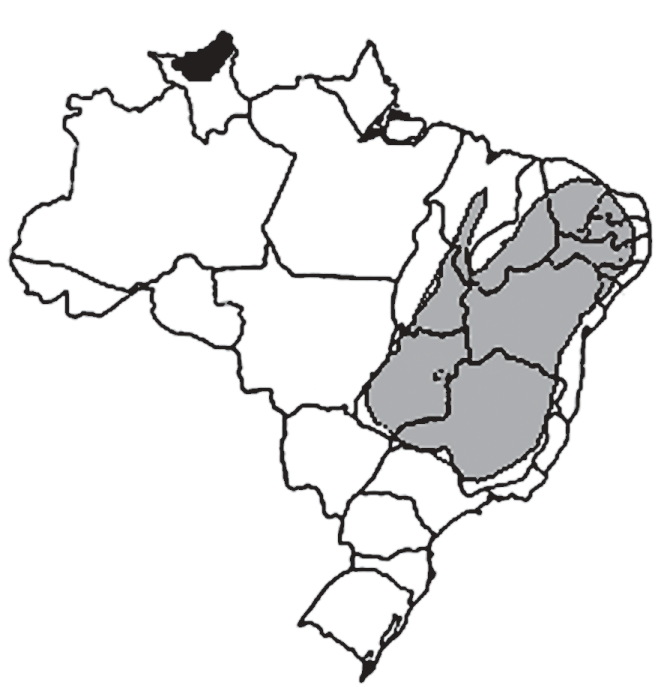

Map of Brazil showing the geographical distribution of Triatoma maculata (black) and T. pseudomaculata (gray) in Brazilian territory (Carcavallo et al. 1999).

ics of the group (Pérez et al. 2005), and (c) experimental hybridizations have enabled quantitative analyses of taxonomic relationships correlated with degrees of morphological similarities between species (Usinger et al. 1966), the present investigation was aimed at broadening our understanding of the degree of reproductive isolation between T. maculata and T. pseudomaculata.

\section{MATERIALS AND METHODS}

Parental specimens of the T. maculata colony were obtained in November 2002 in palm trees locally known as "inajá" (Attalea maripa), in the municipality of

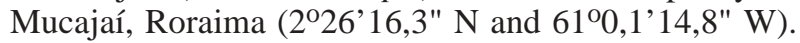
T. pseudomaculata specimens were captured in peridomestic habitats in September 2003 in the municipality of Sobral, state of Ceará (347'22' S and 40²4'08'" W) Brazil, in collaboration with Fundação Nacional de Saúde - Funasa (The National Health Foundation). The colonies were maintained in the insectary of the Laboratory of Triatomine and Epidemiology of Chagas Disease at Centro de Pesquisa René Rachou-Fiocruz, Belo Horizonte, Brazil, in an incubator (at $27 \pm 1^{\circ} \mathrm{C}$, relative humidity $65 \pm 5 \%$ ) and offered weekly feeds on Swiss mice anesthetized with Thiopental. To perform the experiments, either field collected insects or up to the F1 generation, obtained under laboratory conditions, were used.

For inter and intraspecific (control) crosses, 10 couples for each group were used as follows: (1) $T$. pseudomaculata females $\times T$. maculata males; (2) $T$. maculata females $\times T$. pseudomaculata males; (3) $T$. pseudomaculata males $\times$ females; and (4) T. maculata males $\times$ females.

The insects were sexed at the fifth instar and males and females were kept separately with weekly blood-feeding. The couples were introduced no more than three days after the adult molt, and each couple was then kept in a separate container. Each female was checked daily for eggs whose viability was then observed for at least 15 days. Viable offspring were then maintained to the adult stage.

Data obtained from a daily follow up of hybrid offspring were submitted to a parametric statistical analysis (ANOVA) concerning average of laid eggs and hatch time, and a nonparametric analysis (Kruskal Wallis) regarding percentage of hatched eggs. Analyses were carried out through the software Graph Pad Prism version 3.00. Fertility of the hybrids was evaluated from a pool of insects (Table I). Hybrid males and females were kept together and observed weekly for one month to verify the presence of eggs and spermatophore elimination.

\section{RESULTS}

None of the parameters under study showed significantly differences between specific crosses (Table II).

Crosses involving $T$. maculata females showed a lower number of eggs laid (Table II) and a longer hatching period (Table II) when compared with the $T$. pseudomaculata control crosses; whereas, crosses involving T. maculata males showed a shorter hatching period in relation to the $T$. pseudomaculata control crosses (Table II). The percentage of hatched eggs was significantly different only for crosses between T. maculata male and T. pseudomaculata female (Table II) when compared to the T. maculata control crosses. A couple from this group was observed not to have their eggs hatched. Spermatophore elimination by females was noted in order to detect mating between hybrid specimens and backcross hybrids. This provided evidence that hybrids are able to mate, even if they produce unviable eggs.

TABLE I

Backcross groups formed from a pool of hybrids descendants of the cross between Triatoma maculata and T. pseudomaculata and their parental species. The crosses had been kept at $27 \pm 1^{\circ} \mathrm{C}$ and relative humidity $65 \pm 5 \%$ and observed during one month

\begin{tabular}{ll}
\hline Male & Female \\
\hline $\begin{array}{l}\text { Hybrids of the cross between T. maculata male } \\
\text { and T. pseudomaculata female }\end{array}$ & $\begin{array}{l}\text { T. maculata } \\
\text { T. pseudomaculata }\end{array}$ \\
$\begin{array}{l}\text { T. maculata } \\
\text { T. pseudomaculata }\end{array}$ & $\begin{array}{l}\text { Hybrids of the cross between T. maculata } \\
\text { male and T. pseudomaculata female }\end{array}$ \\
T. maculata & $\begin{array}{l}\text { Hybrids of the cross between } T \text {. pseudomaculata } \\
\text { male and T. maculata female }\end{array}$ \\
\hline
\end{tabular}


TABLE II

Average of daily observation of the crosses between Triatoma maculata (Tm) and T. pseudomaculata (Tp) during 15 days since the first laid ( 10 couples for each cross)

\begin{tabular}{|c|c|c|c|c|}
\hline \multirow[b]{2}{*}{ Parameters observed } & \multicolumn{4}{|c|}{ Cross } \\
\hline & $\operatorname{Tm} \sigma^{\star} \times \operatorname{Tm} q$ & $\mathrm{Tp} \sigma^{\top} \times \mathrm{Tp}+$ & $\operatorname{Tm}{ }^{\star} \times \mathrm{Tp}$ 우 & $\operatorname{Tp} \sigma^{\top} \mathrm{x} \operatorname{Tm}+$ \\
\hline Laid eggs & $22,5 \pm 8,1$ & $30,5 \pm 8,2^{a}$ & $21,5 \pm 7,8$ & $21 \pm 5,9^{a}$ \\
\hline Hatching time & $18,1 \pm 0,3$ & $17,2 \pm 0,4^{a}$ & $16,6 \pm 0,5^{a}$ & $19,9 \pm 0,4$ \\
\hline Success (percentageof hatched eggs) & $96 \pm 6,6^{a}$ & $89 \pm 11,4$ & $72 \pm 28^{a}$ & $90 \pm 10,9$ \\
\hline
\end{tabular}

$a$ : different values for each parameter observed $(\mathrm{p}<0.05)$.

\section{DISCUSSION}

Observations of the biology of T. maculata and $T$. pseudomaculata are available from several sources. Espínola et al. (1981) assessed T. maculata crosses under laboratory conditions at temperatures ranging from 26.3 to $32.2^{\circ} \mathrm{C}$, average relative humidity of $60.4 \%$ and with the bugs blood fed on chickens. The number of eggs laid varied from one to 17 eggs a day, with an average daily oviposition of three eggs; $8.1 \%$ of the eggs were infertile. In our study, T. maculata showed an average daily oviposition of 12.6, producing $4 \%$ of infertile eggs. Feliciangeli and Rabinovich (1985) observed an average of 19.1 days of incubation for T. maculata eggs, which is similar to our results, in which average incubation time was 18.1 days. Silva et al. (1995), by studying the influence of temperature on the development of T. maculata blood fed on chicken, verified a difference in the egg incubation period: 29 and 16 days at 25 and $30^{\circ} \mathrm{C}$, respectively. Luitgards-Moura et al. (2005) have also shown that higher temperatures diminish the incubation period; with temperatures ranging from 21.5 to $32^{\circ} \mathrm{C}$ (average $27.6^{\circ} \mathrm{C}$ ) and weekly blood feeding on mice, these authors reported a variation in the period of egg incubation between 14 and 42 days, with a significant negative correlation between temperature and incubation time $(-0.98)$.

Previous investigations on the biology of T. pseudomaculata have shown that the average incubation period is 18 days, at temperatures $28 \pm 1^{\circ} \mathrm{C}$ and $80 \%$ relative humidity, blood fed weekly on pigeons (Gonçalves et al. 1997). These results are in accordance with ours, where temperature and relative humidity were kept at 27 $\pm 1^{\circ} \mathrm{C}$ and $65 \pm 5 \%$, respectively, with an average egg hatching time of 17.2 days.

Our results show no differences between T. maculata and T. pseudomaculata, concerning the number, hatching time, and viability of eggs laid. Besides maintenance conditions, slight differences in the biology of T. maculata and T. pseudomaculata shown here, in relation to previous studies (Gonçalves et al. 1997), might be due to genetic variations among the populations used, and to the length of time that colonies had been kept under laboratory conditions.

At the time of description of T. pseudomaculata, Espínola carried out crosses between T. maculata and $T$. pseudomaculata and verified that they produced unvi- able eggs, mainly when crosses were between $T$. pseudoma-culata males and T. maculata females (Corrêa \& Espínola 1964). In the present study, the eggs hatching period showed no statistical difference in the crosses between $T$. maculata females and $T$. pseudomaculata males, or between $T$. maculata males and T. pseudoma-culata females; $72 \%$ of the eggs laid by $T$. pseudoma-culata females in the cross with $T$. maculata hatched, and $90 \%$ of the eggs laid by $T$. maculata females crossed with T. pseudomaculata were successful. Such results demonstrate that the direction of the crosses did not significantly interfere with embryonic development. A signi-ficant decrease in the percentage of eggs hatched in the cross between $T$. maculata males and T. pseudomaculata females (72\%) was observed in relation to the control cross of $T$. maculata (96\%). However, one must consider that, in this interspecific cross, there was a couple whose eggs did not hatch, a fact that may also occur in intraspecific crosses, probably due to either the male or the female infertility. The interspecific cross with T. maculata female showed the worst results when compared with the control cross with $T$. pseudomaculata; when $T$. maculata males were included in the interspecific crosses, eggs showed a shorter development length than that with $T$. pseudomaculata. Such results show the influence of female T. maculata specimens in relation to the control cross with T. pseu-domaculata.

In accordance with the species concept proposed by Dobzhansky (1937): "a species is a group of fully fertile individuals, but reproductively isolated from other similar groups due to their physiological features (producing any parental incompatibility, hybrid sterility, or both)". The ease with which T. maculata and T. pseudomaculata intercross in the laboratory, despite not producing fertile hybrids in nature, may be explained by the fact that they are allopatric species (Figure). Because they do not co-exist, there would be no selection of features (either morphological or behavioral) that would lead to reproductive isolation between them. Several other triatomine species, morphologically similar or not, genetically close or not, are known to produce hybrids under either natural or experimental conditions (Mazzotti \& Osório 1941, 1942, Abalos 1948, Ryckman 1962, Espínola 1971, Carvalheiro \& Barreto 1976, FrancaRodríguez et al. 1979, Zárate \& Zárate 1985, Galíndez et al. 1994, Pérez et al 2005). 


\section{ACKNOWLEDGMENTS}

To Dr CJ Schofield for English review of this paper.

\section{REFERENCES}

Abalos JW 1948. Sobre híbridos naturales y experimentales de Triatoma. An Inst Regional 2: 209-223.

Borges EC, Pires HH, Barbosa SE, Nunes CM, Pereira MH, Romanha AJ, Diotaiuti L 1999. Genetic variability in Brazilian triatomines and the risk of domiciliation. Mem Inst Oswaldo Cruz 94: 371-373.

Carcavallo RU, Casas SIC, Sherlock IA, Girón IG, Jurberg J, Galvão C, Segura CAM, Noireau F 1999. Distribuição geográfica e dispersão altilatitudinal. In RU Carcavallo, IG Girón, J Jurberg, H Lent (eds), Atlas dos Vetores da Doença de Chagas nas Américas, vol. III, Fiocruz, Rio de Janeiro.

Carcavallo RU, Girón IG, Jurberg J, Galvão C, Lent H 1997. Chaves gráficas para as tribos, gêneros e espécies da subfamília Triatominae. In RU Carcavallo, IG Girón, J Jurberg, H Lent (eds), Atlas dos Vetores da Doença de Chagas nas Américas, vol. I, Fiocruz, Rio de Janeiro.

Carcavallo RU, Jurberg J, Lent H, Noireau F, Galvão C 2000. Phylogeny of the Triatominae (Hemiptera: Reduviidae). Proposals for taxonomic arrangements. Entomol Vect 7: 1-99.

Carvalheiro JR, Barretto MP 1976. Estudos sobre reservatórios e vectores silvestres do Trypanosoma cruzi. LX - Tentativas de cruzamento de Rhodnius prolixus Stål, 1859 com Rhodnius neglectus Lent, 1954 (Hemiptera, Reduviidae). Rev Inst Med Trop São Paulo 18: 17-23.

Corrêa RR, Espínola H 1964. Descrição de Triatoma maculata, nova espécie de triatomíneo de Sobral, Ceará (Hemiptera, Reduviidae). Arq Hig Saúde Públ 29: 115-127.

Dobzhansky T 1937. Genetics and the Origins of Species, Columbia Univ. Press, New York.

Costa J, Felix M 2007. Triatoma juazeirensis sp. nov. from the stateof Bahia, Northeastern Brazil (Hemiptera: Reduviidae: Triatominae). Mem Inst Oswaldo Cruz 102: 87-90.

Costa J, Argolo A, Felix M 2006. Redescription of Triatoma melanica Neiva \& Lent, 1941, new status (Hemiptera: Reduviidae: Triatominae). Zootaxa 1385: 47-58.

Espínola HN 1971. Reproductive isolation between Triatoma brasiliensis Neiva, 1911 and Triatoma petrochii Pinto \& Barreto, 1925 (Hemiptera Reduvvidae). Rev Bras Biol 31: 278-281.

Espínola HN 1974. Duas novas subespécies do "complexo maculata", "Triatoma pseudomaculata pseudomaculata" e "Triatoma pseudomaculata minasensis" (Hemiptera, Reduviidae, Triatominae). Ci Cult 26: 354-355.

Espínola HN, Rodriguez F, Bermudez M, Tonn RJ 1981. Informaciones sobre la biologia y el ciclo de vida de Triatoma maculata (Erichson, 1848) (Hemiptera, Reduviidae, Triatominae), en condiciones de laboratorio. Bol Dir Malariol San Amb XXI: 140-142.

Feliciangeli MD, Rabinovich J 1985. Vital statistics of Triatominae (Hemiptera: Reduviidae) under laboratory conditions II. Triatoma maculata. J Med Entomol 22: 43-48.

Forero D, Weirauch C, Baena M 2004. Synonymy of the reduviid (Hemiptera: Heteroptera) genus Torrealbaia (Triatominae) with Amphibolus (Harpactorinae), with notes on
Amphibolus venator (Klug, 1830). Zootaxa 670: 1-12.

Franca-Rodríguez ME, Yong DG, Lozano M 1979. Estudio sobre los descendientes entre Triatoma infestans (Klug, 1834) y Triatoma rubrovaria (Blanchard, 1843, (Hemiptera, Reduviidae). Rev Biol Urug 7: 101-115.

Galíndez GI, Barazarte R, Márquez J, Oviedo M, Márquez Y, Morón L, Carcavallo RU 1994. Relaciones reproductivas entre Rhodnius prolixus Stal y Rhodnius robustus Larrousse (Hemiptera, Reduviidae, Triatominae) bajo condiciones de laboratorio. Entomol Vect 1: 3-13.

Galvão C, Carcavallo R, Rocha DS, Jurberg J 2003. A checklist of the current valid species of the subfamily Triatominae Jeannel, 1919 (Hemiptera, Reduviidae) and their geographical distribuition, with nomenclatural and taxonomic notes. Zootaxa 202: 1-36.

Gonçalves TCM, Cunha V, Oliveira E, Jurberg J 1997. Alguns aspectos da biologia de Triatoma pseudomaculata Corrêa \& Espínola, 1964, em condições de laboratório (Hemiptera: Reduviidae: Triatominae). Mem Inst Oswaldo Cruz 92: 275280.

Hypša V, DF Tietz, J Zrzavý, ROM Rego, C Galvão, J Jurberg 2002. Phylogeny and biogeography of Triatominae (Hemiptera: Reduviidae): molecular evidence of a New World origin of the Asiatic clade. Molec Phyl Evol 23: 447-457.

Lent H, Wygodzinsky P 1979. Revision of the Triatominae (Hemiptera: Reduviidae), and their significance as vectors of Chagas' disease. Bull Am Mus Nat Hist 163: 123-520.

Luitgards-Moura JF, Vargas AB, Almeida CE, Magno-Esperança G, Agapito-Souza R, Folly-Ramos E, Costa J, Tsouris PRosaFreitas MG 2005. A Triatoma maculata (Hemiptera, Reduviidae, Triatominae) population from Roraima, Amazon region, Brazil, has some bionomic characteristics of a potential Chagas disease vector. Rev Inst Med Trop São Paulo 47: 131-137.

Mazzotti L, Osorio MT 1941. Resultados obtenidos en cruzamientos con especies diferentes de Triatoma. Rev Fac Bogotá 10: 159-160.

Mazzotti L, Osorio MT 1942. Cruzamientos experimentales entre varias especies de triatomas. Medicina 22: 215-222.

Noireau F, Carbajal-de-la-Fuente AL, Lopes CM, Diotaiuti L 2005. Some considerations about the ecology of Triatominae. An Acad Bras Cienc 77: 431-436.

Pérez R, Hérnandez M, Quintero O, Scvortzoff E, Canale D, Méndez L, Cohanoff C, Martino M, Panzera F 2005. Cytogenetic analysis of experimental hybrids in species of Triatominae (Hemiptera-Reduviidae). Genetica 125: 261-270.

Perlowagora-Szumlewicz A, Correia MV 1972. Introduction of male sterility though manipulation of genetic mechanisms present in vector species of Chagas disease. Rev Inst Med Trop São Paulo 14: 360-371.

Perlowagora-Szumlewicz A, Correia MV, Trinxet AMR 1974. Introduction of male sterility II: Onset of disappearance of induced sterility in successive backcrosses. Proc. of Munic FR Germany p. 25-31.

Perlowagora-Szumlewicz A 1976. Male sterility induced trough interespecific hybridization of Triatominae. XV Internacional Congress of Entomology; Washington, D. C.

Ryckman RE 1962. Biosystematics and hosts of the Triatoma 
protracta complex in North América (Hemiptera: Reduviidae) (Rodentia: Cricetidae). Univ Calif Publ Entomol 27: 93-240.

Santos SM 2003. Estudo Molecular de Triatoma pseudomaculata Corrêa \& Espínola, 1964 e Espécies Afins: Rastreamento Genético Populacional e suas Implicações na Taxonomia e Epidemiologia, MSc Thesis, Instituto Oswaldo Cruz, Rio de Janeiro, 90 pp.

Sarquis O, Sposina R, de Oliveira TG, Mac Cord JR, Cabello PH, Borges-Pereira J, Lima MM 2006. Aspects of peridomiciliary ecotopes in rural areas of Northeastern Brazil associated to triatomine (Hemiptera, Reduviidae) infestation, vectors of Chagas disease. Mem Inst Oswaldo Cruz 101: 143-147.

Schofield CJ 1988. Biosystematics of the Triatominae. In MW Service, Biosystematics of Haematophagous Insects, Clarendon Press, Oxford, p. 284-312.
Silva IG, Fernandes FF, Silva HHG 1995. Influência da temperatura na biologia de triatomíneos. XX. Triatoma maculata (Erichson, 1848) (Hemiptera, Reduviidae). Rev Patol Trop 24: 49-54.

Silveira AC, Rezende DF 1994. Epidemiologia e controle da transmissão vetorial da doença de Chagas no Brasil. Rev Soc Brasileira Med Trop 27: 11-22.

Torrealba JW, Tonn RJ, Carcavallo RU 1985. Venezuela. In RU Carcavallo, JE Rabinovich, RJ Tonn (eds), Factores Biologicos y Ecologicos en la Enfermidade de Chagas, Centro Panamericano de Ecología Humana y Salud, Argentina.

Usinger RL, Wygodzinsky P, Ryckman ER 1966. The biosystematics of Triatominae. Annu Rev Entomol 11: 309-329.

Zárate LG, Zárate RJ 1985. A checklist of the Triatominae (Hemiptera:Reduviidae) of Mexico. Int J Entomol 27: 102-127. 
